\title{
Chinese Animation Comes back to the Public Discourse
}

\author{
Xiao $\mathrm{Hu}^{1,2} \&$ Xiaoyu Dong ${ }^{1}$ \\ ${ }^{1}$ School of Journalism and Communication, Southwest University, Beibei, Chongqing, China \\ ${ }^{2}$ School of culture and communication, Chongqing University of Arts and Sciences, Yong Chuan, Chongqing, \\ China \\ Correspondence: Xiao Hu, School of Journalism and Communication, Southwest University, Beibei, Chongqing, \\ China. Tel: 86-139-9628-0289. E-mail: hxo_0@hotmail.com
}

Received: June 15, 2014 Accepted: July 30, 2014 Online Published: August 15, 2014

doi:10.5539/ass.v10n18p25 URL: http://dx.doi.org/10.5539/ass.v10n18p25

\begin{abstract}
There is a Market Analysis Report about Chinese animation towards imported American animations into China. In this report, the problems and the possible opportunities of Chinese animation market will be analyzed, as the principles and ethical standards of animation theme for public discourse is been noticed.
\end{abstract}

Keywords: Chinese animation, public discourse, commercial model

\section{Introduction}

The researches of Chinese animation industry involved contents, characters, strengths and weaknesses, the chances and challenge, the strategies of commercial mode, and culture capital as one element of the animation production or political aims. Doctor Lijun Sun (Note 1) of the Beijing Film School said: "From two years' old to 12 , children are in a process of unknown to known. So the Chinese native animation could be engraved in the Children's hearts as their memory only when it grasp the broadcasting markets of animation. In this case, Chinese animation also has the chance to let the Chinese culture and civilization be known to the children through the film and television which the children can well understand. "Fung, Anthony Y. H. (Note 2) discuss private creative industries, cultural economy, revitalizing old industries as in the cluster models of many western countries. ZHAN Xiaoqi (Note 3) uses SWOT model to analyses the competitiveness of the animation industry. Four factors of manufacture element have been mentioned, cultural demanding, performance of enterprises, strategic mode competitor, performance of relative and under exploited industries. Wenjie Li (Note 4) diversified extension strategy of animation industry chain.

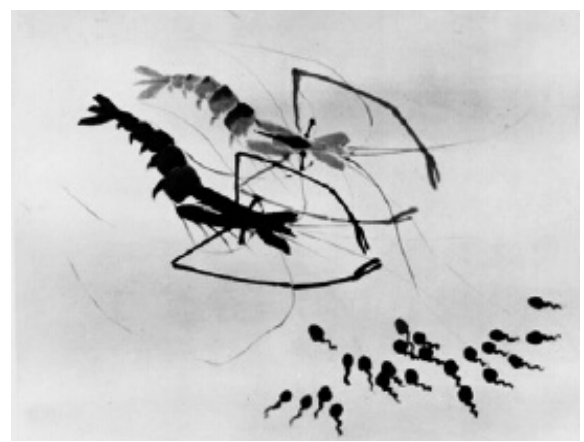

Figure 1. Baby tadpoles look for their mother

\section{Method}

\subsection{The Scale of This Paper}

In this paper, we set the limit to discuss about the economic appearance and the culture public discourse of animation. It first will be analyzed the Chinese animation and American developed in mainland China. Then it will be pointed out the reason why the various cultures can be accepted by the world audience as elements in the animations. 


\subsection{Chinese Animation History}

Animation communicates ideas and culture of various countries as a culture production. "Chinese Animation" has been famous in the world because of its style with humorous Children language, Chinese classical story, Chinese monochromes and Beijing opera, e.g. Adventures in the Heavenly Palace, Baby Tadpoles Look for Their Mother. Nowadays, the Public Discourse of Public Entertainment, Reward the Right and Punish the Wrong, Respect for Humanity, Happiness and Growth is embraced in various nationalities' animation, and the intellectual creations of different nations become common property of the world.

\subsection{Chinese Animation Performances In 2013}

Chinese movie and animation had good achievements in 2013. The total income of movies in mainland China has been 21767 million RMB in 2013, include native movies of 12767 million, and international movies of 9002 million. There has been 358 Chinese TV Cartoon of 204732 minutes this year with continually descending compared with last two years, which is a good news for the explosive growth of Chinese animation production with high energy consumption and low efficiency around 2010.33 animation movies has shown in the main cinemas in Mainland China this year with 1640 million RMB income, 21\% higher than in 2012.In which 24 Chinese animations (include 2 Cooperative) acquire revenues of 628 million RMB, 57\% higher than the year before. The point is, Chinese animation have been $38 \%$ of the total animation movies broadcasting in mainland China, $9 \%$ higher than the year before. (Note 5)

The scores of single movies have been good based on the ranking in 2013.In 2012,there had been only one Chinese animation movie called Adventures On The Dragon's Trail acquire revenues exceed 50 million RMB. Adventures On The Dragon's Trail which had been shown in 2012, continually keep good grades as the only Chinese animation movie with totally up to100 million RMB incomes in mainland China. In the other hand, Adventures On The Dragon's Trail, the fourth edition of the series animation movies of Pleasant Goat and Big Big Wolf, has acquired revenues declined than the before's.

Chinese Animation market attracts movie companies which have not animation production as traditional film enterprises. In 2013, many Chinese film giants entered into the animation force for enclosure of the animation market. Huayi Bros. Media Group collaborated with Creative Power Entertaining to be one of the producers of the animation series Pleasant Goat and Big Big Wolf. BONA participated in the film distribution of Kuiba2.ENLIGHT MEDIA deserved the Movie promotion and distribution of The Saier3: Ares Alliance. Beijing Galloping Horse got joint works in Happy Heroes. Chinese animation production has been the favorite for film giants overnight. Kexin Liu, the ECD of Taikang Works said, the giants will take part in animation only when the market fledged enough. Chinese animation producing scale had been too small to attract the big companies to join in. She admits Taikang Works had got close relationships with main cinemas before Legend of the Moles' success; they collaborated with Motion Pictures Group in 2011, with SMI in 2012, like many film corporations without animations before. Wu Dun, The CPO of Creative Power Entertaining, said, Chinese animation's success changes the views of capital market. Banks begins to lend to the animation companies with only scripts but real estate that can't be imagine before. It is no doubt that there will be more and more traditional film enterprises jumping into the animation area for a slice of the cake. Although big film corporations joined in the animation market, it is just a try of investment. The traditional enterprises just take part in investment and publishing, without deeper collaboration.

\subsection{The Threaten from American Animation in 2013}

Table 1. Animation movie ranking TOP10 in mainland China, 2013

\begin{tabular}{llll}
\hline Ranking & Name & Country & Box Office (million RMB) \\
\hline 1 & The Croods & American & 394 \\
2 & Monsters University & American & 210 \\
3 & The Smurfs 2 & American & 138 \\
4 & The Mythical Ark: Adventures in Love Happiness & China & 125 \\
5 & Turbo & China & 113 \\
6 & The Saier3: Ares Alliance & China & 76 \\
7 & Hotel Transylvania & American & 74 \\
8 & Adventures On The Dragon's Trail & China & 69 \\
9 & Happy Little Submarine 3Rainbow & China & 57 \\
10 & Epic & American & 49.9 \\
\hline
\end{tabular}


American animations import in China has got a better achievement than Chinese animations in 2013.They have got most movie box office in China. Chinese animations as same as Chinese movies, are facing the threats from American, 9 American animations movies shown in the mainland China cinemas in 2013, 4 of which receive exceed 100 million RMB, 5 in which got into the top 10 ranking as the following Table 1, cover all of top 3 ranking, with obviously superiority'.

As seen from the table, the six Hollywood's animation movies acquire box office of 978 million RMB, which has been $57 \%$ of all animation box office in mainland in 2013.In which The Croods has been the champion with 394 million RMB box offices, 24\% of all. Chinese animation needs more efforts.

\subsection{Analysis of the Problems of Chinese Animation}

\subsubsection{The Small and Medium Animation Enterprises Lack Power for Completion}

There are two problems of Chinese animation left. First, Most of the animation companies in mainland China are small and medium enterprises. Chinese economic policy supports them just as a drop in the bucket, although it is good enough compared to American and Japan. The most animation companies can't afford the long-time creative work and box office risk, and some of them choose animation subcontracting. On the other hand, animations like Adventures on the Dragon's Trail have not matured enough teamwork and capital to compete with the empire enterprises like Hasbro.

\subsubsection{Chinese Animation Lack Film Classification System}

The second, there is not film classification system in China, which is different from American MPAA and Japanese. That is because the government has a specialized agency (State Administration of Radio Film and Television, SARFT) to manage the movie or TV program which broadcasting in China. But it still makes troubles in international movie market when Chinese animation exported to the countries which abandon the entrance of the non-classification film to the main cinemas, adhere to the film classification rules. Still on the other hand, the non-classification system brings troubles that Crayon Shin-chan, which is been limit broadcasting in Japan, shown to the young and old at will in mainland China. At the same time, the 2008 edition Calabash Brothers, Rainbow Cat and Blue Rabbit had been criticized for violence. As a result, the Chinese animation has problem in economic and management system.

\subsubsection{The Problems of the Public Discourse}

The public discourse of Modern media, show the mass interesting and joining in Political affairs, public affairs and public interests. Chinese Media have transformed from absolute political discourse to the public political discourse, and constructed Media Public Discourse System with the developing market-oriented economy and democratization. The construction of which responded to the expectations of public participation in state affairs, public affairs, the maintenance of public interests and private interests. It makes sense for social progress and development Chinese media itself.

"Public discourse" provides the premise for the development of personality though praising the privacy, but with a strict division of public and private spaces, individual aliened. According to America new historicism view "social energy", a release of space is needed by social energy flow of non-rationality, for the construction of public discourse space. At the same time, the private space is firming in Public Domain, and the social energy transfer channel is blocked. As described in Eliot's poem "wilderness"," Everyone's feet just stare at her toes; everyone kept his own cell, listening to the neighbors keys jingling." Then Social Ability will accumulate, expansion and evolution of violence, so Post Modern critics attempted to reconstruct the conversational public discourse with private fusion. They wished Dialogue instead of monologue, removing the main (body) priori, and emphasizing readers feel and clamor.

Since the second half of the twentieth Century, the situation has changed. Paper media gradually declined with the rise of mass media broadcast, television, network and so forth. Mass media connects the scattered individual with dissemination advantages as never before, becoming the public discourse space. The mass media has become the main way of modern people and the outside world. Public discourse, such as political, military, law, religion, education, must enter the mass media before the public discourse space. The general impression of mass media is entertainment based on its kitsch trait. Every public discourse gradually arises with entertainments to be cultural soul. Just as Neil Boatman said in Amusing to Death "We will finally amusing ourselves to death." If seek public discourse seriously in TV, you will discovered yourself a less active citizen than a passive consumer, less active searching than passive acceptance, less stimulated initiative action than getting numb.

In China animation "bears", with characters bears and Bald Qiang, are favorated by parents and the children's. The well selling has its reason that a new kind of characters, loony tone and the life of the funny plot, the 
character Bald Qiang who similar to the singer Xue Cun with the song The Guys in Northeast is Helpful which is popular in China, make the children simmer with laughter, let the adults relax from works. In the time when Chinese crave entertainment, expect domestic classic animation, the animation sales skyrocketed. In 2013, Bears, together with Pleasant Goat and Big Big Wolf, were blamed by the public opinion. This condemnation is reasonable, Bears and Bald Qiang always use violence to solve problems, Bears turns from protecting forest to the action bullying the Bald Qiang, acted "Wire barbecue" scientific knowledge error, burning down the log cabin, while deforestation turned to endless game. "The protection of forest" theme was replaced by the competitions with crooked ways of Bears and Bald Qiang, Maybe we can argue that the animation shouldn't promote the theme of protection of forest if actually for entertainment, or it should be included some environmental protection knowledge in animation, as well as stimulating the audience's awareness of environmental protection by examples, if indeed its theme is Protect Forest.

Animation the issuer and the audience actually knows that the theme "protect the forest and love" was good for Children audience, as well as the entertainments for parents, who were sharing the living room and TV with Children, but finally universal entertainment replaced the initial theme.

Since the entertainment is the "true meaning", then the plot of animation will naturally develop with it, like Wire barbecue, burning down the log cabin, Destroying the meager possessions of bald Qiang, and Make Bald Qiang homeless, who is Civilian, life oriented, strong sense of reality. The entertainment with less compassion being shown and replayed to the children lack of social experience may not be a protection of Children heart of gold. It is the reason why animation Bears drawn fire.

However, in 2014, the criticizing disappeared from the scene with the New Year's bell ringing, was replaced by Actor Zhang Wen Betrayed his Wife, World Cup and so forth. Then where is our conclusion and action to the error in animation? No conclusion, not Even Sense, people just keeping watching the animation Bears and its sequel.

Director Rod Lurie told an embarrassing story of public discourse in entertainment media in 2008. The reporter was arraigned and held in detention by the government because of a Pulitzer Prize winning news report Involving state secrets and the image of the president. The public express their dissatisfaction and anger through the media, the reporter's lawyer also saw success in the public support. But with the case dragged on, the most important bargaining chip to win the lawsuit-the public, lost enthusiasm for the case, because the topics attracting public are too many to focus on every day. The feat making the reporter to be a hero maybe equal to a third level star with drug problems. The film reveals a terrible reality for us: The public only need constantly retrofit topics in the media entertainment era, rather than the topics itself and the reasons or significance as well as the deeper thinking. All Significance of the Media Signifier can find its Entertainments Significant Orientation finally, when grabbing the attention of the audience in the media; the audience has unscrambled the meaning of the media information in dazed. Popular culture and gossip become the favorite topics of the public,

\subsection{Solutions Explorations for Economic Problem Above}

\subsubsection{The Suitable Commercial Modes Are Needed by Animation Companies}

As more and more animation professionals comes into the animation industry, Chinese animation is not short of good originality and contents, but good teamwork. Weimin Huang, directed Pleasant Goat and Big Big Wolf said, animation need the good teamwork, excellent script, popular platform, productions development of the animation, sales performance and money flowed back. There are Zhejiang Economic, Made in China, New Sea and Blockbuster (Note 6) commercial mode of animation in China, none of which can solve problems completely which the small and medium animation enterprises faces above. The Japanese commercial mode called Film Partners maybe a solution. The principle of the mode is: Enterprises who join in the Film Partners continually decreases the management risk of the enterprise and continue to strengthen the division and cooperation of small and medium enterprises. The committee of Film Partners takes responsibility for the coordination and profit sharing. Animation production, sales, television and derivatives productions are operated by Membership Corporation. Nausicaa of the Valley of the Winds had firstly adopted this mode and succeeded. The Film Partners mode has been widely adopted in Japan now.

\subsubsection{Animation Public Discourse Call for "Companionship and Growth"}

Equal importantly to above two problems, Animation creation should capture animation public discourse "companionship and growth". The Swiss psychologist Carl Jung think analysis: The original image is a psychological balance and compensating of the problem we face in the day life. For each significant experience, each kind of profound conflict will wake up the precious storage the image accumulation. Hayao Miyazaki 
Animation has touched people's hearts, because we find ourselves experienced agony, happiness, sad, friendship, family love, war as we have done before in the animation like Spirited Away or Hotaru No Haka. It is amazing which we can't reach in the real life in Howl's Moving Castle, Princess Mononoke. "Companionship and growth" as animation theme is public discourse of world, root in the desire for security, justice, compassion, achievement of people. Animation is a wide area people can experience children's interesting, funny, justice, imaginations of animation composers in it. The Public discourses Public Entertainment, Reward the Right and Punish the Evil, Respect for Humanity, Happiness and Growth are waiting for communicated broadly and innovation.

\section{Results}

Chinese animation has been developing with rough from the animation Noisy Studio in 1926, and recovered in 1974 with several years interrupt in the Great Proletarian Cultural Revolution. In spite of this, China animation has great development potential roots in the Chinese culture mines include Chinese classical story, Chinese monochromes, Beijing opera and so forth. The developing world makes us think deeply about the economic and cultural influence of animation of the world. When you win the audience in the cinema, sometimes it means the audiences accept your idea, your culture, to a certain extent, your national spirits. We shouldn't slow the animation cultural communication when developing for economic reasons, which is an important reason of lacking big brand of animation in China. We should come back to the original point of animation culture with public welfare and art as well as developing our animation industry, because culture would have no power if put the culture as only a commodity.

\section{References}

Chen, J. H. (2009). The Digestion and Deconstruction of Public Discourse in Entertainment Era. Journalism Lover, 24-25.

Chinese Central TV. (2014). Retrieved June 11, 2014, from http://donghua.cntv.cn/2014/01/27/ARTI139081 6405533971.s.html

Fung, A. (n. d.). Cultural clusters and cultural industries in China. Inter-Asia Cultural Studies, (14), 644-656.

Guang Ming Daily. (2007). Retrieved December 7, 2007, from http://www.gmw.cn/content/2007-12/07/ content_707182.htm

Han, M. Y., \& Zhang, F. (2010). Analysis of animation commercial modes of China and other countries. Special Zone Economy, 95-97.

Ran, H (2007). The construction of Public Discourse in China. Wuhan University Journal (Humanity Sciences), 710-715.

Wen, J. L. (2009). An Analysis on the Diversified Extension Strategy for China's Animation Industry. Asian Social Science, 178-180.

Zhan, X. Q. (2013). A SWOT analysis of Chinese animation industry's international competitiveness. Journal of Liaoning Technical University, 479-484.

\section{Notes}

Note 1. Guang ming Daily. (2007). http://www.gmw.cn/content/2007-12/07/content_707182.htm

Note 2. Fung, A. Cultural clusters and cultural industries in China. Inter-Asia Cultural Studies, (14), 644-656.

Note 3. ZHAN Xiaoqi. ASWOT analysis of Chinese animation industry's international competitiveness. Journal of Liaoning Technical University, 479-484.

Note 4. Wen Jieli. An Analysis on the Diversified Extension Strategy for China's Animation Industry. Asia Social Science, 178-180.

Note 5. CCTV. http://donghua.cntv.cn/2014/01/27/ARTI1390816405533971.s.html

Note 6. Minyong Han, FeiZhang. Analysis of animation commercial modes of China and other countries. Special Zone Economy, 95-97.

\section{Copyrights}

Copyright for this article is retained by the author(s), with first publication rights granted to the journal.

This is an open-access article distributed under the terms and conditions of the Creative Commons Attribution license (http://creativecommons.org/licenses/by/3.0/). 